CAKRAWALA LINGUISTA

e-ISSN: 2597-9779 dan p-ISSN: 2597-9787

This work is licensed under

a Creative Commons Attribution-NonCommercial 4.0 International License.

\title{
Models of Language Teaching and Humanizing Education
}

\author{
Rosida Tiurma Manurung \\ Program Magister Psikologi Sains Universitas Kristen Maranatha Bandung \\ E-mail: rosidatm@gmail.com
}

\footnotetext{
Keywords :

models of language teaching; humanism; teachers; students; the modern era
}

\begin{abstract}
Modern, digitalized, high tech, global era characterized by the development of sciences has transform human beings into heartless machines with no sense of humanity and no concerns to their surrounding environment. Therefore, education should be packed with loads that include the perspective of humanism. Education should not be interpreted as a mere class teaching-learning activity. Education should refer to the various processes and activities that should be productive; creative; develop skills, personality, integration, and excellence; and up to moral and spiritual reinforcement. Education shall be managed and directed with clear objectives, which are capable to develop positive values in learners. Education should be able to create figures with solid and proven character and personality both in the field of science and the humanities. Humanizing education means it is capable to produce human with sense of "humanity" which is characterized by the willingness to help others; empathy; honesty; share; loyalty; the willingness to take valuable lessons; persistent and tenacious,; high-respect of pluralism; tolerance; respect to others; patience; replied good for evil; always puts the good rather than evil, continuous efforts to improve the quality of charity and kindness; humility; and sincere. Therefore, the teaching materials must also be interpreted, filled, and imbued with the messages of humanity. These entire facts mean that teaching materials are not mere "soulless and empty" materials since if it is, then the materials will be like empty casket with no benefit to human life and livelihood. Approach of humanism in modern era education is considered as the most appropriate solution since this kind of education has education activities that don't works like the machines do, and this means the students, teachers, and teaching materials should also be "humanized" in order to achieve educational goals optimally and in accordance with the vision and mission carried. This research discuss model of language teaching with humanistic perspective. Hopefully, through language teaching with humanism approach, students and teachers may rediscover the "human side" that may have been lost and undetected.
\end{abstract}




\section{INTRODUCTION}

The recent era has changed the mindset, the pattern of social relationships, consumption patterns, and the human pattern of view of life. On the one hand, this is a result of the growth and development of the era through the movement of modernism that stems from the paradigm of Western thought. On the other hand, it is also a compulsion which must be experienced when society has no choice but to follow the dominance of Western thought. The recent era has brought about social change in human culture. All spheres of life, from economy, politics, education, transportation, information, to art, rearranges with a more current perspective. Rationalization is established as a means to achieve the ideals of free, critical, and universal. Science and technology is a modernization agent that will make it happen.

Science and technology have indeed brought meaningful change to mankind. As a cutting-edge agent, these two areas have made life easier, effective, and fast-paced. Humans compete to advance technology and science as darts darting through boundaries that were previously too strong to break down. Rationalization, exploration of reality, and unlimited experiments, is the basic concept of this ideology. Industrialization, information and communication technology, and transportation are instruments to make it happen.

The universal liberty and freedom of mankind must be established through the use of unlimited ratios. It is this belief that then marks the emergence of excitement and passion to apply sophistication as the only movement that can improve human dignity. The future of mankind lies in a continuity of life and consciousness. Without it, progress and growth of humanity will be remarkably slow. How left behind a nation when it rejects such a development paradigm. As a result, in any hemisphere, the movement of modernism becomes the only inevitable choice. The latest era is characterized by globalization, advances in information technology, modernization, and the development of science that brings impacts on Indonesian society.

The modern era of modern, global, high-tech, all-digital era, characterized by the growing knowledge of science has pushed people like machines that have no heart, no sense of humanity, and do not care about the surrounding environment. Therefore, education must be packed with content that has a humanism perspective.

In essence, education should not be interpreted as an activity or teaching and learning activities in the classroom only. Education should refer to the various processes and activities that must be productive, creative, skill developers, personality, integration, excellence, until the moral and spiritual strengthening. Education should be directed and managed with a clear purpose, which is able to develop positive values in learners. Through education, we should be able to bring out the figures that have the character and personality that is strong and tested, both in the field of science and in the field of humanity.

\section{METHOD}

In this research, descriptive analysis method is used, that is the problem is discussed with facts obtained in the field. Zulnaidi (2007) says that descriptive method can be interpreted as a procedure or problem-solving method that is investigated by describing the existence of research objects (person, institution, society, and so on) in the present with reference to the facts that appear or as it is.

Based on the above understanding, it can be concluded the characteristics of descriptive method in this study.

1) Focus on the problems that exist at the time of the research done (at present) and actual problems.

2) Describe the facts that have a close relevance to the issues being investigated as they are, concrete, factual, without being interfered by personal opinions. 
In order for the use of methods in this study to achieve goals and to be successful, descriptive methods are applied with data collection techniques based on surveys, relationship studies, and developmental studies.

\section{RESULTS AND DISCUSSIONS}

\section{A. Humanizing Education Model}

Teachers are less creative utilizing existing facilities to optimize learning media. Secondly, the learning activities are still dominated by lecture method and the learning process is less varied so that less accommodates the difference of learning styles of students. Third, the planting of religious values does not become an important part of language learning. Fourth, oopportunities for students to perform communicative activities, both in the classroom and outside the classroom are still lacking. Fifth, the lack of effort to create a conducive language environment in order to increase the motivation of students to practice the language they learn.

The application of a humanistic approach to language learning in schools starts from the formulation of lesson plans, their implementation in methods and learning techniques, to evaluation. Implementation of learning certainly cannot be separated from the current curriculum. Education Unit Level Curriculum (KKNI) 2013 is a curriculum that has characteristics of humanistic approach, because it not only oriented to the achievement of mere material, but also sided with the basic needs of students. However, of course humanization efforts in language learning are not enough to be realized only in the formulation of the curriculum, but rather the full support and consistency of all educational stakeholders, and especially the earnest efforts of teachers to be able to implement them in classroom learning.

With this humanistic approach, language teachers can create a learning process that contributes greatly to the character building of the students, and helps them to develop their full potential. In addition, the applied humanistic approach can train students to be able to learn independently, trained to think critically and creatively, and generate considerable confidence to speak.

\section{B. Humanizing Language Education Model}

One of the impacts of language is to reinforce positive values in the mind and human persuasion. Humans can be creative, broad-minded bias, even biased to be a good leader when he draws the values poured by authors in the work of language. Language can be said is always a very important part of any civilization in the world. The community that taps can be interpreted as a society that has the courtesy and goodness of character or can also be interpreted as a polite society and have advanced life inner level.

Another role of language is the spread of science. Language is created by utilizing the nuances of science as well as the pattern of life of society and nation. In the works of language often found reviews about iptek yamg developed leh figures, or new discoveries.

In the current era, language teaching in schools can use a humanistic perspective, namely:

1. Developing and cultivating positive human values, such as helping, doing good, believing, and piety;

2. Teach moral messages to human beings, especially leaders, to do what is in accordance with the expectations of society, love justice, truth, and honesty;

3. Encourage people to work hard for their own interests and common interests;

4. Strengthen and nurture the personal character, identity and resilience of a positive, strong and strong nation, in order to achieve the ideals of the nation and state.

Efforts to strengthen the identity and resilience of the nation should be done as early as possible, i.e. since childhood. Children should be treated to language readings that contain positive plots and 
characters, showcase the diversity of cultural values, and accompanied by interesting and captivating illustrations of local cultural treasures characterized by Indonesia.

In the world of education, teachers must be keen to choose teaching materials that are loaded with local traditions and cultural values. In the process of language learning, teachers must use multicultural language learning methods, train students to appreciate local values that educate, positive, and noble. Of course, in the selection of language works to be appreciated must be tailored to the cognitive and psychological abilities of learners.

The government, in this case the Department of National Education, should dare to incorporate multicultural language learning with local color in the curriculum of primary, secondary, or even higher education. Thus, the teaching of local values in the language becomes embedded.

In terms of teachers themselves, teachers must be willing to teach the language in the classroom, do not just want to teach the language only. Teaching languages does require special skills. Teachers must also reconstruct their mindset in a multicultural perspective.

Language books are a source of language learning, but those stored in school libraries are few and limited. Therefore, the government and the community should be encouraged to hold a fund-raising program to add a collection of language books in school libraries in both big cities and remote schools.

Society should be counseled and enlightened that the difference is beautiful, must be respected, and accepted. Indonesian people should be taught and given examples of tolerance, loyal friends, not imposing wills, not playing their own judges, and not thinking of themselves and their groups.

The Information and Communications Department should expressly filter out less educational, vigilant, violent, ethnically and pornographic television shows. In addition, strictly porn sites must be blocked and closed. Through television shows and news in the print media, it can be inserted with the teachings of tolerance, self-control, morality, politeness, and nationalism in society.

Linguist is encouraged to continue giving birth to works of language that reflect Indonesia and strong localities. The linguist should have raised themes highlighting the treasures of cultural wealth, local wisdom, morality, manners, religion, social class differences, ethnic and cultural differences, gender differences, and love of the nation. Linguist consciously or unconsciously has become the main actor in an effort to strengthen the identity and resilience of the nation so as to realize humanization in education. Thus, in the future, human beings of Indonesia are getting better in quality both intellectually and morally.

The following are language teachings that can "humanize" learners, teachers, and teaching materials.

1) The provision of language teaching materials that can connect teachers, learners, and the environment, for example learners should make a report on interviews with teachers, friends, and communities around the school about "spirit of togetherness". With the theme of "spirit of togetherness" can cultivate a sense of unity among the ethnic, caring, and love of the homeland. Students can be encouraged to cultivate a sense of humanity.

2) Provision of tasks of analyzing and appreciating local literary works that contain cultural diversity, eg Robohnya Surau Kami, a work by A.A. Navis, which presented the setting and wealth of Minangkabau culture, Umar Khayam's Priyayi revealing Javanese nuances and ideologies, Antologi Puisi written by D. Zawawi Imron highlighting Madurese culture, Korrie Layun Rampan's Upacara revealing the existence of the Dayak, Bila Malam Bertambah Malam the work of Putu Wijaya that exposes the richness of Balinese culture, and Clara Ng's Dim Sum Terakhir by describing life in Chinese ethnic settlements.

3) In language learning in the classroom, there must be an interaction between teachers and students. Interaction is mutual action, there is a reciprocal relationship, there is a two-way communication. Interactions are of course dynamic, not static. In language learning, verbal interaction is most prominent and dominant. 
4) Need the design of tasks that empower the character and humanistic to the learners. For example, providing group assignments in the form of analysis reports of interviews to small traders selling near the campus. In addition to the students apply the theory of interview techniques and report writing, they are also touched to realize care or concern to the little wong. In addition, the assignment of group discussions by role play, forcing learners to empower their national character. With role play, they can be creative in playing the character, synergize with others, train the role, train the sensitivity, and train to actualize themselves. Role play in language learning, for example, plays the role of overseas students enrolled in big cities who are ridiculed by their friends for using Indonesian language accent interefered by regional language mixing with the Indonesian language. In addition to the achievement of teaching materials that are language interference, as well as role play activities can foster moral values that respect peoples, pluralism, and each person has a uniqueness. Assignment can be done by utilizing computer technology, such as creating creative, innovative, and full of creative and animated point of view when learners present their tasks.

5) With a humanistic approach, we can design rules in the classroom. For example, rules should not be cheated, rules should not be late, well-dressed rules, rules on shoes, rules do not activate mobile phones, do not eat or drink in class, pray before and after learning, and other rules that can empower national character skills. In language learning, we can apply the rules of "standard, good and correct language use zone" in the class if any of the violations may be fined (eg Rp5000.00 per violation and the result can be donated to foster care program).

6) Learners can also develop themselves actively in theater activities, arts units, sports, study groups, and research groups to improve the character of nationality and sense of humanity.

7) To support language learning with a humanistic approach, activities such as class-class debates, presentation of research findings by learners in public, poetry reading contest with musicalisation, use of computer technology in making posters about taglines / political expression that build and educate nation, and so forth.

8) As a form of humanistic language-measured language study in rotation every parallel class once a week teaching in elementary school the majority of students are children of weakminded parents Students are trained to become volunteers to help their younger siblings learn a good Indonesian language and true, learning to write, and learning to read. The sensitivity of the learners to empathize, to feel the condition of concern, to witness firsthand the suffering of life, and to know that there are some communities or groups who are economically disadvantaged finally make learners appreciate life and life. Exercise to be a volunteer can develop the national character and multi-cultural understanding of learners.

\section{CONCLUSION AND SUGGESTION}

Based on the above discussion, the things found are as follows.

1. Language is able to establish positive local values in the minds and feelings of the Indonesian nation.

2. Language is capable of being a filtering device or an influence filter from the outside.

3. Language is a very important part and plays a role in the civilization of any nation anywhere in the world.

4. Language teaching can be used as a tool to nurture national character.

5. Teaching language can be used as a means to "humanize" learners, teachers, and teaching materials.

6. Children should be treated to language readings that contain positive plots and characters, showcase the diversity of cultural values, and be accompanied by interesting and captivating illustrations of local cultural treasures characterized by Indonesia so that they can become human beings of character and become complete human beings, who love to the nation and country, caring for others, and upholds morals. 


\section{REFERENCES}

Alwi, Hasan. (1999). Telaah Bahasa dan Bahasa. Depdiknas: Pusat Pembinaan dan Pengembangan Bahasa.

Cultural Studies. (2000). Teori Bahasa Pengantar Komprehensif. Jakarta: Jalasutra Egleton Terry.

Gulo, W. (2002). Strategi Belajar-mengajar. Jakarta: Gramedia.

Masrukhi. (2009). "Revitalisasi Pendidikan IPS sebagai Instrumen Integrasi Nasional". Dalam Integrasi Sosial dalam Bermasyarakat majemuk pada Era Global. Universitas Negeri Semarang: Fakultas Ilmu Sosial.

Zulnaidi. (2007). Metode Penelitian. Medan: Universitas Sumatera Utara. 